\title{
Media capture with Chinese characteristics: Changing patterns in Hong Kong's news media system
}

\section{Nicholas Frisch}

Yale University, USA

\section{Valerie Belair-Gagnon}

University of Minnesota, USA

\section{Colin Agur}

University of Minnesota, USA

\begin{abstract}
In the Special Administrative Region of Hong Kong, a former British territory in southern China returned to the People's Republic as a semi-autonomous enclave in 1997, media capture has distinct characteristics. On one hand, Hong Kong offers a case of media capture in an uncensored media sector and open market economy similar to those of Western industrialized democracies. Yet Hong Kong's comparatively small size, close proximity, and broad economic exposure to the authoritarian markets and politics of neighboring Mainland China, which practices strict censorship, place unique pressures on Hong Kong's nominally free press. Building on the literature on media and politics in Hong Kong post-handover and drawing on interviews with journalists in Hong Kong, this article examines the dynamics of media capture in Hong Kong. It highlights how corporate-owned legacy media outlets are increasingly deferential to the Beijing government's news agenda, while social media is fostering alternative spaces for more skeptical and aggressive voices. This article develops a scholarly vocabulary to describe media capture from the perspective of local journalists and from the academic literature on media and power in Hong Kong and China since 1997.
\end{abstract}

\section{Corresponding author:}

Valerie Belair-Gagnon, Hubbard School of Journalism \& Mass Communication, University of Minnesota, Murphy Hall 329, 206 Church St SE, Minneapolis, MN 55455, USA.

Email:vbg@umn.edu 


\section{Keywords}

China, digital media, Hong Kong, journalism, media capture, media production, social media

\section{Introduction}

Until 1997, Hong Kong was a British territory; that year, a handover negotiated between London and Beijing returned the enclave's sovereignty to the People's Republic of China (PRC) under the 'one country, two systems' constitutional principle formulated by China's paramount leader Deng Xiaoping.

The 'one country, two systems' agreement committed the Beijing Central government to preserving Hong Kong's economic system, British-style independent judiciary, free press, and professional civil service, while Beijing took responsibility for external defense and foreign affairs. The agreement sought to preserve civic and economic freedoms inherited from the British. Since the handover, Hong Kong's media system has experienced changes in its ownership structures, editorial freedom, and underlying economic and political conditions (Cheung, 2003; Fung, 2007; Pen America Center, 2015). Global media watchdogs have found a de facto decline in Hong Kong's press freedoms, despite the de jure protections afforded by the 'one country, two systems' agreement. These shifts suggest a type of media capture that is particular to Hong Kong's relationship with Mainland China. Existing literature, and our findings, suggest that despite Hong Kong's autonomy and lack of a de jure censorship system (such as the media control apparatus in neighboring Mainland China), the two decades since the handover have seen a steady increase of Mainland China's economic and political influence over Hong Kong's civic life and a corresponding erosion of media independence.

\section{Conceptualizing media capture in Hong Kong}

By media capture, we refer to the exercise of Mainland Chinese political and business influence over Hong Kong's historically independent press through the re-negotiation of power and media, via media practices and norms that mirror Mainland China's authoritarian media practices. Hong Kong's example illustrates how news media can be quietly and unofficially captured via a convergence of interests between business and government. As Sparks (2010) argued, the links between the media and political systems are not the sole means of comparing media systems. Similarly, this article calls for 'a much broader approach to the societies under consideration and then for a more conflictcentered view both of those societies and of their mass media' (Sparks, 2010: 554).

Media capture can involve overt government coercion within a state's sovereign borders (Herman and Chomsky, 1988; Shirk, 2010), indirect control through influencing ownership (Hanson and Yosifon, 2003), or softer pressures influencing reporting agendas and practices. In Hong Kong, owners of broadcast and print legacy media outlets often own assets in Hong Kong and the much larger market of Mainland China, which make them vulnerable to Communist Party pressures. This economic reality increases media owners' incentives to exercise editorial control over their media platforms. As 
legacy media outlets increasingly defer to Beijing's preferred news agenda, online media and citizen journalism have become more aggressive and skeptical (Pen America Center, 2015). Because of the relatively smaller number of major broadcasting outlets and the simplicity of their ownership structure, these are not the focus of our article. We look at the more liquid and granular market of print periodicals (and associated web content), whose fractured systems of ownership and control clearly capture and illustrate the media capture phenomenon.

The Chinese Communist Party does not see overt control over domestic media in Mainland China and less explicit coercive measures to shape news narratives in uncensored markets like Hong Kong's, as matters of 'capture'. Rather, these are part of an effort to promote the Party's preferred narrative of developments in Chinese economy and society and limit rumors and provocations. In Beijing's eyes, Hong Kong media outlets may indeed already be 'captured' - by the values and viewpoints of Western corporate and political interests - and in need of liberation, a process of influence most easily exerted on corporate legacy media owners with wide financial exposure to mainland Chinese markets.

By contrast, social media platforms and 'new' media sites in Hong Kong exist predominantly on platforms and sites owned by Western corporations (e.g. Facebook or Google) with a presence in Hong Kong. These sites and platforms have little market exposure to Mainland China because they are blocked by the 'Great Firewall', the Mainland Internet censorship system which is not applied to Hong Kong (Lin, 2016). These new media outlets are in many respects the least captured parts of Hong Kong's media system, a result of Hong Kong's connectivity to the outside world, China's decision to block major Western platforms on the mainland, and the capture of Hong Kong's legacy media. Today, even as its legacy media are being drawn more closely into the orbit of Mainland China, Hong Kong has developed a robust, largely uncaptured set of alternative media.

To examine this interplay, this article uses the concept of 'capturing the uncaptured' to study changes in Hong Kong's media system since 1997. Among Hong Kong local journalists, there is an increasing sense that legacy media is corporately and editorially captured. Yet even as its legacy media are being drawn more closely into the orbit of Mainland China, Hong Kong has robust, uncaptured alternative media. For a free press in Hong Kong, the emerging sites of contention are digital media outlets that still enjoy independent ownership and editorial policy and have yet to face the same economic pressures as legacy media. By focusing on mainland efforts to 'capture the uncaptured', we highlight the distinct features of digital media in Hong Kong, as well as the growing economic, political, and cultural influence of Mainland China in Hong Kong.

Studying media capture in Hong Kong since 1997 is important for several reasons. In the nearly two decades since the handover, Hong Kong's media industry has experienced a subtle but steady increase in Mainland China's economic and political influence. China's levers of influence over Hong Kong's mass media are partially a result of intentional 'opinion guidance' [舆论引导] policy from Beijing, a broader public relations policy aimed at influencing media narratives beyond Mainland China. But Hong Kong's media capture phenomenon is also driven by the territory's broad economic exposure to Mainland China and Hong Kong tycoons' fear of offending Mainland authorities, whose 
cooperation is essential to their business interests (Pen America, 2015). Several scholars and media practitioners have argued that much of the last few decades' erosion of media independence, and the capture of media outlets, has occurred through anticipatory selfcensorship with little direct input from officials in Mainland China (Cheung, 2003; Fung, 2007; Pen America Center, 2015). To date, the academic literature ${ }^{1}$ has addressed the tensions between power and media in two distinct yet intertwined places, Mainland China and Hong Kong (Cheung, 2003; Fung, 2007; Lee, 1998). There is a need for a contemporary study that builds on academic literature on media in Hong Kong using indepth interviews with Hong Kong-based reporters.

This article has three parts. First, it discusses the context: the political and economic changes that have led to media capture. Second, it elaborates on how media capture has worked in practice, including editorial policies, ownership, and the blurring of the lines between Hong Kong and Mainland China's media. And third, it explores how new media (e.g. digital first sites, social media, and mobile chat applications) have offered alternative spaces where tensions play out between the captured and the uncaptured in Hong Kong's news media.

\section{Methodology}

This article builds on the literature on media capture in Hong Kong and draws on 34 anonymized informal interviews with China and Hong Kong-based journalists and researchers from mainstream local journalistic and academic institutions, working primarily in Chinese and secondarily in English. Interviewees were reporters and editors and came primarily from legacy media organizations that originated as print periodicals.

In-depth interviews allowed us to explore the tensions of 'capturing the uncaptured' news media in Hong Kong. Our questions used an inductive approach and probed journalists' daily news processes, changes in institutional norms and practices since the handover, and journalists' perceptions of China's role in Hong Kong media. After reading transcripts, we coded interview segments that pertained to 'editorial' and 'corporate' media capture. In coding, two categories emerged: 'capture of new media' and 'uncaptured media'. At the request of the respondents, interviews are anonymized.

\section{Power and counter-power in Hong Kong's media: A literature review}

The scholarly literature has identified ways that, since the handover, the Chinese government has asserted increasing political control over Hong Kong's news media (Cheung, 2003; Fung, 2007; Ma, 2007). In their study of interactions between media and Mainland China power centers, Chan and Lee (2013) found that 'structural factors such as the policy of "one country, two systems" and the operation of a vibrant media market set limits on the pace and extent to which journalistic paradigms shift' (Chan and Lee, 2013: 140-146). They found that 'energized public opinion' and a public 'revision of political parallelism' are useful lenses for viewing Hong Kong's media system.

Yet, since 2014, the rise of new media (especially Facebook and WhatsApp), paired with increasing public angst about Chinese government influence over Hong Kong's 
media, has led to the emergence of alternative and segmented online media spaces. According to Kwong (2015), during a recent protest movement against Beijing's moves to sharply delimit Hong Kong's democratic development, 'most mainstream media organisations took an anti-movement stance and practiced self-censorship so as not to offend the Chinese government' (Kwong, 2015: 273). As a result, in 2014, many Hong Kong people turned to digital media to criticize Hong Kong's mainstream media and support the Umbrella Movement, while older and more conservative Hong Kongers turned to legacy media (particularly television). As Kwong (2015) argued, 'overall, online media have created an alternative political space attracting critically minded and democratic-oriented Hong Kong citizens'.

Chan and Lee (2013) called for more empirical research to attend to explore the contradictions in Hong Kong's media politics as well as 'identity and conceptualize recurrent patterns, emerging phenomena, strategies used by various actors and specific mechanisms' (Chan and Lee, 2013: xi) with determined outcomes. In order to understand today's media capture, the following section lays out the socio-political changes in Hong Kong that led to today's participatory online culture.

\section{Hong Kong's media system, 1945 to today}

\section{Prologue: A free press with colonial characteristics, 1940s-1970s}

Hong Kong's modern media history begins in 1945, when the colony was returned to British control by surrendering Japanese forces. As a neutral zone in China's civil war between Chiang Kai-shek's faltering Nationalist Party and Mao Zedong's ascendant Communist Party, Hong Kong received waves of refugees from Mainland China, including intellectuals fleeing repression and business tycoons fearful of expropriation. With the Communist victory over Mainland China in 1949, British Hong Kong became the media industry hub of the Chinese-speaking world, as well as the main Western observation post for developments in Communist China and the broader region. Hong Kong's news media landscape was a robust and mostly free market in commercial and civic-minded media in both Chinese and English, as well as other Asian and European languages for diaspora communities based in the colony (Cheng, 1997).

With a colonial government run by a professional British-style civil service and a Governor appointed by London, Hong Kong enjoyed a high level of press freedom under a common-law framework modeled on Britain's (Bereuter, 1997). The British colonial government's laissez-faire policies generally tolerated Communist newspapers (e.g. $\mathrm{Ta}$ Kung Pao 大公報, Wen Wei Po 文匯報), Kuomintang Nationalist newspapers (e.g. Hong Kong Times 香港時報, Hong Kong United Daily 聯合報), highbrow moderate newspapers (e.g. Ming Pao Daily News 明報, Hong Kong Economic Journal 信報, South China Morning Post 南華早報), entertainment tabloids (e.g. Next Magazine 壹週刊), and a large variety of other foreign and local print and broadcast news media (Ma, 2007).

After a period of flux in the 1950s-1960s, press barons such as Louis Cha and Shum Choi-sang dominated the news media business in ways similar to Western press owners, with several families and wealthy individuals exercising control over most of the major Chinese and English media outlets. Through the end of the 1970s, Mainland China's 
socialist command economy and isolation from the capitalist world meant that Hong Kong's media business had little financial or reputational incentive to consider the wishes of Mainland authorities or consumers. Beijing policy-makers and Communist Party censors blocked Mainland media market access, and Hong Kong's capitalist tycoons had no business interests on the Maoist Mainland. ${ }^{2}$

\section{Disruptions: Economics and politics from the Mainland, 1980s-1990s}

Change to this political and economic status quo began in the early 1980s (Gupta, 1996; Loh, 2010). After the death of Mao Zedong, Deng Xiaoping's policy experiments in market economics encouraged inbound investment from Hong Kong. In May 1980, Shenzhen, a fishing village over the border from Hong Kong, was designated a Special Economic Zone. Deng gave theoretical sanction to the mainland's experiments with capitalism under the euphemism 'socialism with Chinese characteristics', which describes limited free-market mechanisms designed to foster growth, but under supervision of, and open to veto by, Communist Party leaders. Hong Kong's businessmen opened factories in Shenzhen, taking advantage of China's cheap labor and kickstarting a three-decade economic boom. The Communist Party invited Hong Kong businessmen deemed 'patriotic', such as Louis Cha and business magnate Li Ka-shing, to Beijing to meet high-ranking Communist Party leaders, including Deng. In doing so, Beijing opened a channel of dialogue to discuss Hong Kongers' growing business interests in Mainland China and open the political question of Hong Kong's future after the expiration of London's treaty lease in 1997.

In the 1980s, in political and economic negotiations, London's politicians and Hong Kong's business élites sought two objectives. The first was to preserve Hong Kong's common-law system, independent judiciary, media freedom, anti-corruption mechanisms, and financial and monetary regulatory framework, which were and remain systemically important to global commerce (Chanjaroen, 2016; The World Bank, 2016). The second objective was to preserve good relationships with Communist leaders in Beijing, whose approval was essential for foreign and Hong Kong firms' access to China's billion-strong consumer market and whose cooperation was helpful to the United Kingdom and allied powers (e.g. the United States and Australia) on a variety of political and diplomatic priorities (Garver, 2016; Matthew et al., 2008). The 'one country, two systems' agreement meant that China would retake sovereignty of Hong Kong in 1997, stationing symbolic People's Liberation Army garrisons in the territory, as well as preserving colonial-style civil service, police force, independent judiciary, financial system, and common-law media freedoms. Hong Kong's system is encoded in the Basic Law, a mini-constitution that makes the territory almost a de facto city state under Chinese sovereignty, with separate laws, courts, currency, customs, immigration, and media regulation (Hualing, 2014).

Despite frictions over the interpretation of the Basic Law and the 'one country, two systems' agreement, Hong Kong's press business has remained free of the formal censorship mechanisms that restrict media workers over the border in Mainland China. In the Mainland, media outlets operate under state licenses that can be revoked at any time; journalists can be given internal demerits or suspensions over coverage that displeases senior officials; departments at all levels of government issue guidelines on how (or 
whether) sensitive topics are to be covered, the kinds of language and framing that are impermissible, and what types of investigations are off-limits (Weiss, 2013).

This complex de jure censorship bureaucracy has no formal jurisdiction in Hong Kong. Yet there is a long history, predating the 1997 handover, of the PRC government seeking to influence Hong Kong news media (Sciutto, 1996). And in the years since the handover, the PRC government has increased its efforts to gain leverage over the Hong Kong press, making active use of a system of rewards, punishments, and public relations.

When China resumed sovereignty over Hong Kong, Beijing's own practices and expectations of the proper role of media in society differed starkly from Hong Kong's liberal model. This clash in media traditions has led to a series of informal re-negotiations in media practices and norms in Hong Kong's news media, undertaken through changes in ownership and editorial practice without any de jure change to Hong Kong's legal framework. As a result, while the laws protecting Hong Kong media remain in place, a new set of norms and practices has emerged, driven by the growing economic and political leverage of the PRC over Hong Kong's internal affairs (Cook, 2013).

\section{The growth of a digital participatory culture in Hong Kong media, 2000s to today}

Post-handover, the growth of Internet penetration and proliferation of smartphones and tablets have subjected Hong Kong's legacy media to economic and structural pressures similar to those faced by their Western counterparts (Interviews with journalist and columnist, 2016). These include declines in print circulation and advertising revenues, and a resulting need to produce the news under new financial constraints (Yeung, 2015; Interview with columnist, 2016). In Hong Kong, online-only publications are often specialized (and thus adept at focusing on particular topics and targeting certain demographics), nimble, and able to operate with lower costs. Hong Kong has become home to a flourishing ecosystem of digital first media, including StarExpress, InMediaHK (香港獨 立媒體), and D100. In recent years, these and other online publications have gained popularity and respect as authoritative sources of news (Kwong, 2015; Lin, 2016).

Many of these digital-only outlets came to prominence during recent political turmoil in Hong Kong, as younger media consumers felt that legacy media outlets lacked credibility due to their eroding independence. In response, to bring a pro-government view into new media spaces dominated by government-skeptical voices, Robert Chow, veteran pro-government journalist and former editor-in-chief of The Standard (from 1985 to 1990), launched his own news website, 周融 (chowyung.com), initially with mobile chat applications (e.g. WeChat and WhatsApp) and social media (e.g. Facebook). For younger audiences, social media and online news offer inclusive horizontal communication. These economic and structural pressures, combined with the relatively small size of Hong Kong's economy, have made Hong Kong's legacy media more vulnerable to Beijing's economic and political pressures (Chan and Lee, 2013; interview with columnist, 2016).

In this context of economic change, the PRC government has expanded its repertoire of inducements and disincentives to shape Hong Kong's media discourse. The journalists we interviewed in Hong Kong had a tendency to sound an alarm against mainland extensions 
of control. According to our interviewees, the local press has been systematically defanged and its independence compromised. The most recent World Press Freedom Report, published by Reporters Without Borders, ranks Hong Kong 70th in the world for freedom of the press. That is 9 places lower than in 2014 and 36 places below Hong Kong's ranking in 2010. One representative example of the decline in press freedom came when Ming Pao fired a media executive 'after he ran a front-page story focusing on well-known local politicians and businessmen who had been named in the 'Panama Papers' investigation' (Forsythe and Wong, 2016; Reporters without Borders, 2016).

The most recent report by Freedom House (2015) provides details on current challenges for journalists and news organizations in Hong Kong. That report assigns Hong Kong a rating of Partly Free, with declines in freedom of expression, belief associational and organizational rights. The report highlighted several growing problems: 'The number of physical attacks on journalists increased during the year, major businesses withdrew advertising from critical media outlets, and reporters acknowledged the growing practice of self-censorship' (Freedom House, 2015: 1). The exact methodology and rankings of these and similar reports differ; in all of them, however, Hong Kong has seen a precipitous decline since the handover in 1997. The following section explores how media capture functions in Hong Kong with media ownership and editorial policy. It also shows the tensions that exist in Hong Kong's participatory digital culture, with ongoing efforts by Mainland China to capture the uncaptured.

\section{Media capture and the emergence of a participatory media culture}

This section discusses three ways that the concept of 'capturing the uncaptured' characterizes the contemporary relationship between Mainland China and Hong Kong: ownership, editorial policy, and the blurring of the line between Hong Kong and Mainland Chinese media. This section shows that social media and the Internet have allowed for the rise of a participatory culture, with low barriers to participation and strong support for sharing (Jenkins, 2006), and that this development has created palpable tensions among media organizations.

\section{Ownership}

One visible form of media capture is the ownership of major publications; this arises before changes in editorial policies. In general, Hong Kong news media are banned or heavily censored in China. This means that Hong Kong media firms are not directly incentivized to self-censor for fear that their own media products (e.g. newspapers and magazines) will be restricted from the Mainland market; that restriction is already in place. Rather, many Hong Kong media outlets are owned by conglomerates with major business interests in Mainland China, including fixed assets such as manufacturing plants or real estate developments, which require Communist Party assent to remain in operation and profitable (Fung and Lee, 1994). ${ }^{3}$ A Hong Kong-based columnist corroborated, 
Hong Kong media used to be owned by what we call 'the old money'. Those are what we call the 'top tier families'. They owned the newspaper and then gradually as the boss of the family get old, many of them are selling out, like in the case of Hong Kong Economic Journal. Interesting enough, the Hong Kong media is in a very competitive environment. We have 3 million daily [newspapers sales] every day and our population is only about 7 million [...] almost everyone should have one paper on hand. This is highly competitive and there are 17 daily newspapers, four radios, four TV stations. That explains all the bottom lines of the media are terrible. (Interview with journalist, January 2016)

In some cases, major Hong Kong corporations that rose to prominence under British administration owned news media outlets in Hong Kong prior to the 1980s economic reforms in Mainland China. In Hong Kong's Cold War climate, Beijing's socialist system and generally hostile attitude toward the West meant that, for many media outlets and their owners, there was little financial or reputational downside in producing journalism with negative portrayals of China's policies and leadership. This incentive structure changed when Mainland China's markets opened to Hong Kong investment.

In other instances, conglomerates with growing business interests in China acquired previously independent news media outlets. In 1995, Tiong Hiew King, a ChineseMalaysian timber mogul with business interests and close ties to the Mainland, bought the Chinese-language newspaper Ming Pao Daily News (明報) with its Toronto and Vancouver editions. In 2014, Lam Shan-muk, the founder of the Hong Kong Economic Journal (HKEJ) (信報) sold all his shares to Richard Li, the son of Hong Kong tycoon Li Ka-shing. Li maintained that the acquisition would have no impact on editorial direction of newspaper (Ejinsight, 2014; Lam and Lau, 2014). And in 2015, Alibaba bought the South China Morning Post (SCMP), saying that it wished to shape a more 'sympathetic coverage of China' in the newspaper: '[i]t is about being impartial and balanced [...] We should offer a fair chance to readers [to understand what is happening in China], not just a fair chance to China' (Chung-yan, 2016).

Hong Kong's market-dominating radio and television news media outlets, TVB (Television Broadcasts Limited) and RTHK (Radio Television Hong Kong), were originally patterned on the British Broadcasting Corporation's model of editorial independence in public broadcasting. These outlets have also shown signs of deference to Beijing's preferred news narratives. Many Hong Kong reporters view this media capture phenomenon as consistent with a general tendency of the Hong Kong government, whose permanent employees and political appointees have nominal autonomy yet seek a cooperative relationship with their Mainland counterparts, anticipating or deferring to Beijing's implicit preferences in policy and personnel (Hong Kong Journalists Association, 2016a, 2016b; Lee and Chan, 2010; Levin and Yung, 2016). As of 2016, the Hong Kong Journalists Association (2016a) reported that 80 percent of media owners in Hong Kong received appointments or awards from Mainland and pro-establishment groups (e.g. the National People's Congress and the Chinese People's Political Consultative Conference (CPPCC)). According to the Hong Kong Journalists Association (2016a), 31 percent of Hong Kong mainstream media outlets are now in the hands of Mainland corporations. Among Hong Kong journalists, these changes in media ownership have led to a sense that the editorial policies of their news organizations are being captured by individuals and institutions representing Mainland China's interests. 


\section{Editorial policy}

A second form of media capture is editorial policy. An owner of a news media outlet picks its editors and other key personnel and, as a result, shifts in ownership often lead to changes in editorial personnel and direction (Interview with Hong Kong-based columnist, 2016). For example, in 2009, the Hong Kong edition of Esquire magazine, published under license by the South China Media Group 南華傳媒, sacked a reporter who publicly exposed the spiking of her piece on a memorial for the anniversary of the June 1989 Tiananmen Square crackdown. In January 2014, the Ming Pao Daily News, the respected daily acquired in 1995 by Malaysian timber magnate Tiong Hiew King, demoted Kevin Lau, a veteran local journalist and the Chief Editor of the newspaper. He was replaced by a Malaysian-Singaporean journalist without significant local experience. Later that year, an interim editor ordered a last-minute change of a headline; the altered version underplayed sensitive political developments in Hong Kong (BBC, 2014; Initium Media, 2014; Pen American Center, 2015; Yeung, 2014).

Since 2000, the SCMP, once considered the Pacific Rim's English-language paper of record, has fired several columnists whose articles were routinely critical of the Chinese government (Landler, 2000; Ma, 2007). And in 2015, the SCMP fired four veteran journalists (Philip Bowring, Steve Vines, Kevin Rafferty, and Frank Ching), three of whom have been government critics. Although these journalists were told that the editorial decision to terminate their contract was not based on the stories they wrote, their replacements have tended to show Mainland China in a more positive light (Asia Sentinel, 2015; RTHK, 2015; Shanghaiist, 2015; Interview with columnist, 2015).

Similarly, after the 2014 HKEJ's ownership change to Li, the newspaper saw drastic changes in its editorial structure (Hang-chi, 2016). For example, in 2015, the HKEJ dropped the newspaper column of Lai Chak-fun, a veteran pro-democracy commentator. Reflecting on this editorial change and his newfound ability to speak freely on his personal website, Lai wrote, 'I did not feel sad and was relieved. Rather than staying in the "jar" and associating with the evil, I would sooner choose to leave and not bury myself with them' (Quoted in Cheng, 2015).

There are several other recent instances of media capture by editorial policy change (Interviews with journalists, 2016). The difficulty in quantifying gradations of editorial judgment in these episodes and gauging their severity limits observers' ability to point to any single instance as an unambiguous case of self-censorship caused by owners' deference to Beijing. But in the aggregate, a picture emerges of a steady erosion of Hong Kong media independence and a reduced willingness by leading media institutions to investigate authority, both in Mainland China and in Hong Kong (Interview with columnist, 2016). Yet Sciutto (1996) found that the erosion of news in Hong Kong started even before 1997. In other words, Hong Kong media have seen a slow institutional movement away from a Western liberal model (Hallin and Mancini, 2004) to an authoritarian corporatist model (Sparks, 2010).

In addition to their concerns about Hong Kong media outlets converging with mainland media in style and substance, interviewees worried about the growing share of Mainland media in Hong Kong's local media market. Mainland films, television broadcasts, and books are gaining increasing market share in Hong Kong. And conversely, 
more Hong Kong media are also now tailored for the Mainland market (e.g. Phoenix TV). In some cases, a conglomerate's media properties will place broader political considerations above the editorial independence of a specific media outlet. A columnist described such outlets as 'media concubines':

They are there to serve whatever political calls from Beijing. And because [media is] not a business itself, the big difference between these [media concubines] and what we see in a media in the business world is that it has to make profits so it has to listen to its consumers' or readers' taste. (Interview, 2016)

While there are numerous cases of legacy media being captured by changes in ownership and editorial policy, there are also media outlets (especially digital media) trying to remain uncaptured. Often, the resistance has come from the newsroom, creating conflict with management and owners. And with a new participatory culture among journalists, these disputes can spill out into the open. For example, during the editorial upheaval at Ming Pao, that newspaper's journalists kept up critical coverage of ownership interference in the newsroom through dedicated Facebook pages (e.g. Ming Pao Staff Association, Support MP Editorial, Arts Support Ming Pao, and Ming Pao Staff Group pages). The following section lays out how new media are trying to remain uncaptured.

\section{Participatory culture in a society struggling with media capture}

The interplay of 'old' and 'new' media is at the heart of the media capture question in Hong Kong and is important in the development of the media capture concept. While some traditional print publications face new pressures in ownership and editorial policy, Hong Kong has seen the emergence of new, autonomous media outlets and a participatory digital culture. In this sense, Hong Kong is the site both of media capture (of legacy print publications) and of efforts (by new media outlets) to avoid being captured. Legacy media outlets are more vulnerable to capture due to the structural incentives of the people who own the physical assets behind those platforms (e.g. print, broadcast infrastructure, or manufacturing facilities in Mainland China). But as long as Facebook and Google remain popular in Hong Kong and blocked in Mainland China, those corporations will have fewer incentives and face less pressure for their media platforms to be 'captured'.

This article thus argues that a dichotomy has developed in Hong Kong media: legacy media are being captured for structural reasons, while 'new' media are resistant to media capture for similar structural reasons. The history of media capture in Hong Kong is mainly a history of legacy media capture; digital and social media provide a counterpoint. While Hong Kong remains a viable market for print and broadcast media, it also has a high level of Internet and mobile technology penetration. In recent political unrest in Hong Kong, there have been instances of younger, pro-protest demographics that have complained that coverage by legacy media has been 'incomplete' or 'unfair', leading to a rise in the readership of news on online first sites such as Apple Daily. This dissatisfaction is paired with a flourishing of new media voices on nascent digital-only news sites or on platforms such as Facebook (Lee and Chan, 2010; Timmons and Guilford, 2014). 
Under 'one country, two systems', Mainland China's 'Great Firewall' system of Internet censorship does not extend to Hong Kong. Facebook, Twitter, Google, and other digital platforms blocked in China are thus widely used among Hong Kongers. The Western corporations that provide these platforms are almost completely blocked from access to Chinese consumers, meaning that, compared to locally based Hong Kong companies in any sector, their current exposure to the Mainland Chinese market is minimal. Facebook has become the default political debate platform for many Hong Kongers; during protests, activist groups have often posted their main political communications on Facebook, following up sometimes on WhatsApp, and only rarely by e-mail. Legacy media picked up and distributed these messages (Belair-Gagnon et al., 2017; Cheng, 2014, 2016).

Thus, digital-only media, hosted on platforms owned by corporations without wide exposure to Mainland China, are exceptions to the broader trend of media capture. Unlike their counterparts at legacy print publications, less-established self-proclaimed 'citizen journalists' and political activists do not need to rely on legacy media to distribute their message to a wide audience. Today, legacy media outlets are no longer the only gatekeepers between an opinionated citizen and a broader audience. Most Hong Kong legacy news media organizations have, like their Western counterparts, built up major capabilities to push their content onto social media platforms, meaning that any online discourse contain considerable 'captured' media outlet content from legacy media. VJMedia (輔仁 媒體), Independent Media Hong Kong (香港獨立媒體), The Stand News (立場新聞, formerly the House News 主場新聞), and Passion Times (熱血時報) are examples of digital first news platforms established by grassroot activist groups where citizens can also publish commentaries (Cheng, 2014, 2016). These sites allow people to express a government-skeptical view and help activists mobilize supporters, something that legacy media outlets are becoming less willing to offer.

These online media spaces may prove to be susceptible to corporate and intelligence interests aligned with Beijing. In the aftermath of the 2014 Umbrella Movement protests in Hong Kong, which caused an upsurge in 'uncaptured' new media sources, the easy connectivity and contentious issues discussed on these platforms created echo chambers and polarization, which led to fracturing and distrust within the protest movement. Thus, even new media spaces that may be structurally resistant to 'capture' in the conventional sense discussed above may still have their impact blunted through misinformation and diversion techniques practiced by both corporate and state actors advancing Beijing's interests in Hong Kong. An example of this is the 'Fifty Cent Party' or 五毛党, online brigades of paid commenters who post and share messages supportive of the government's position. Widely used to control digital discourse in Mainland China, these paid commenters began appearing on Hong Kong message boards and disrupting, or providing disinformation in, local Hong Kong discourse surrounding the movement (Radio Free Asia, 2015).

\section{Discussion: Capturing the uncaptured}

Many media freedom organizations (e.g. Reporters Without Borders, Committee to Protect Journalists or Freedom House) and scholars (e.g. Cheung, 2003; Fung, 2007; 
Lau, 2008; Ma, 2007) suggest that the Hong Kong media system is in the process of being captured by government and business forces in Mainland China. The Chinese government has sought to influence press coverage in Hong Kong since before the 1997 handover, through the 'United Front' program reaching out to intellectuals, artists, journalists, businessmen, and other people of influence who might be skeptical of the regime (Loh, 2010; Rawnsley and Rawnsley, 2003). While these efforts are not new, the financial rewards for businesses that wish to enter the Mainland market have grown significantly since the 1980s. Correspondingly, the scale and urgency of such efforts has increased during Hong Kong's recent political unrest, as Beijing has tried to shape the discourse toward narratives more favorable to the regime.

What is new today is that Hong Kong legacy media face the economic and structural challenges many legacy media face in Europe and North America, making them more vulnerable to capture. Also, the PRC is richer and more regionally powerful than it was in 1997. In this new economic context, Hong Kong is no longer able to maintain strong separation from the PRC; its media, like its economy, are subject to strong gravitational pull from the Mainland.

This article has shown how Hong Kong's media system has evolved from a largely skeptical and independent press, often driven by commercial considerations toward sensationalism, into an industry that is increasingly captured by, and deferential to, the intertwined business and political interests of the Communist Party in Beijing and its corporate allies in Hong Kong (Fung, 2007; Lai, 2007; Lee, 1998; So, 2007). These changes in Hong Kong's news media provide an entry point for journalists and scholars wishing to understand contemporary media developments in Mainland China and Hong Kong. Looking beyond the 2014 protests, the media ownership and editorial transformations that have taken place in Hong Kong media since 1997 are important factors in the power dynamics of media capture in a changing participatory media culture.

Hong Kong is a unique case because its media sector and economy are similar in structure and operation to a Western industrialized democracy; yet Hong Kong's small size, and massive economic exposure to a neighboring market policed by an authoritarian regime, make it a stark case study. This article identifies in Hong Kong the power of money to capture a media sector without directly employing the traditional tools of authoritarian coercion. Media capture in Hong Kong has implications for other media markets, such as the Hollywood entertainment industry, with potential exposure to Mainland China (Kokas, 2017).

This article has argued that the uncaptured outlets of participatory social media and digital first outlets in Hong Kong are useful counterpoints to the capture of legacy news media. They are products of the easier global permeation of digital media platforms created by foreign corporations (e.g. Google, Facebook, WhatsApp, or Twitter). They enjoy relative economic autonomy compared to Hong Kong legacy news media, whose markets and physical assets are concentrated in Hong Kong and, through their corporate owners, highly exposed to Mainland China. While we see an important ownership and editorial capture in legacy media, it is less the case for social media and digital first sites.

Local Hong Kong news media are not the only media being tamed by China. Future research on how media capture takes place in foreign media organizations 
will help journalists, scholars, and news consumers monitor changes in Hong Kong's media system. Such research can consider how corporatist and authoritarian media dynamics influence media markets beyond their borders, especially if those markets are politically, legally, and culturally distinct. Studies of Hong Kong news media should emphasize patterns in the negotiation of media and authority in Hong Kong. Such studies would have two broad contributions: they would monitor the power struggles of an independent press facing economic and political threats, and examine institutional and journalistic culture in a politically and economically dynamic part of the world.

\section{Funding}

The author(s) disclosed receipt of the following financial support for the research, authorship, and/ or publication of this article: This paper was supported in part by the Tow Center for Digital Journalism at Columbia University.

\section{Notes}

1. In order to make the paper transparent to non-specialists, we have emphasized Englishlanguage sources. However, the lead author reads and speaks Chinese and ensured that our sources for the paper were based on deep knowledge of Chinese-language media and related literature. Many of our interviewees also worked primarily in Chinese-language media.

2. The official body responsible for censorship in Mainland China today is the State Administration of Press, Publication, Radio, Film and Television, which reports to the Publicity Department of the Communist Party of China.

3. Deng Xiaoping's earliest and most successful experiment with market capitalism, the Special Economic Zone of Shenzhen, was designated in 1980 due to its location directly adjacent to the then British Hong Kong.

\section{References}

Asia Sentinel (2015) Leading columnists purged at Hong Kong's paper of record. Available at: http://www.asiasentinel.com/politics/putsch-columnists-south-china-morning-post (accessed 10 November 2016).

BBC (2014) Hong Kong news editor Kevin Lau improving after attack. Available at: http://www. bbc.com/news/world-asia-china-26380267 (accessed 4 November 2016).

Belair-Gagnon V et al. (2017) The changing physical and social environment of newsgathering. Social Media + Society, 3(1).

Bereuter D (eds) (1997) Hong Kong's Reversion to the People's Republic of China: Hearing before the Committee on International Relations, U.S. House of Representatives. Washington, DC: Diane Publishing.

Chanjaroen C (2016) Singapore edges ahead of Hong Kong as No. 3 financial center. Available at: http://www.straitstimes.com/business/banking/singapore-overtakes-hong-kong-as-worldsno-3-financial-centre-survey (accessed 20 November 2016).

Cheng EW (2014) Between ritualistic protest and perpetual struggle: Transformation of activism in postcolonial Hong Kong. Available at: https://www.psa.ac.uk/sites/default/files/conference/papers/2014/Between\%20Ritualistic\%20Protest $\% 20$ and\%20Perpetual\%20Struggle.pdf

Cheng EW (2016) Street politics in a hybrid regime: The diffusion of political activism in postcolonial Hong Kong. The China Quarterly 226: 383-406. 
Cheng J (1997) The Other Hong Kong Report. Hong Kong: Chinese University Press. Available at: http://www.atimes.com/article/fear-and-loathing-in-hong-kong-purging-and-expandingming-pao/

Cheng K (2015) Hong Kong economic journal axes column of veteran pro-democracy commentator. Available at: https://www.hongkongfp.com/2015/12/25/hong-kong-economic-journal-axes-column-of-veteran-pro-democracy-commentator (accessed 10 November 2016).

Cheung ASY (2003) Hong Kong press coverage of China-Taiwan cross-straits tension. In: Ferdinand P, Ash R, Hook B, et al. (eds) Hong Kong in Transition: One Country, Two Systems. London: Routledge, pp. 210-225.

Chung-yan C (2016) Alibaba's Jack Ma reveals why he bought the South China morning post and what he wants to do with it. Available at: http:/www.scmp.com/news/china/society/article/1937256/alibabas-jack-ma-reveals-why-he-bought-south-china-morning-post (accessed 10 November 2016).

Cook S (2013) The long shadow of Chinese censorship: How the communist party's media restrictions affect news outlets around the world. Available at: http://www.cima.ned.org/wp-content/uploads/2015/02/CIMA-China_Sarah\%20Cook.pdf (accessed 10 November 2016).

Ejinsight (2014) HKEJ now fully owned by Richard Li. Available at: http://www.ejinsight. com/20140902-hkej-now-fully-owned-by-richard-li (accessed 10 November 2016).

Forsythe N and Wong A (2016) Timing of editor's firing Has Hong Kong worried about press freedom. New York Times. Available at: http://www.nytimes.com/2016/04/21/world/asia/ hong-kong-ming-pao-editor.html (accessed 10 November 2016).

Freedom House (2015) Hong Kong report. Available at: https://freedomhouse.org/report/freedomworld/2015/hong-kong (accessed 10 November 2016).

Fung A and Lee C (1994) Hong Kong's changing media ownership: Uncertainty and dilemma. International Communication Gazette 53(1-2): 127-133.

Fung AYH (2007) Political economy of Hong Kong Media: Producing a hegemonic voice. Asian Journal of Communication 17(2): 159-171.

Garver J (2016) China's Quest: The History of the Foreign Relations of the People's Republic of China. Oxford: Oxford University Press.

Gupta SP (1996) China's Economic Reforms: The Role of Special Economic Zones and Economic and Technological Development Zones. Beijing, China: Allied Publishers.

Hallin DC and Mancini P (2004) Comparing Media Systems. Cambridge: Cambridge University Press.

Hang-chi L (2016) Ads and editorial freedom: My time with the HKEJ. Available at: http://www. ejinsight.com/20160506-ads-and-editorial-freedom-my-time-with-the-hkej (accessed 10 November 2016).

Hanson D and Yosifon DG (2003) The situation: An introduction to the situational character, critical realism, power economics, and deep capture. University of Pennsylvania Law Review 152: 129.

Herman E and Chomsky N (1988) Manufacturing Consent. New York: Pantheon Books.

Hong Kong Journalists Association (2016a) On country, two nightmares, Hong Kong media caught in ideological battleground. Available at: https://www.hkja.org.hk/site/Host/hkja/UserFiles/ file/annualreport/Annual_report_2016_Final\%20V.pdf (accessed 10 November 2016).

Hong Kong Journalists Association (2016b) Survey reveals worrying trend of confidence decline in press freedom. Available at: http://www.hkja.org.hk/site/portal/Site.aspx (accessed 10 November 2016).

Hualing F (2014) When can the people's liberation army intervene in Hong Kong's umbrella revolution? Available at: http://researchblog.law.hku.hk/2014/10/when-can-peoples-liberationarmy.html (accessed 10 November 2016). 
Initium Media (2016) Fear and loathing in Hong Kong: Purging and expanding Ming Pao. Available at: http://www.atimes.com/article/fear-and-loathing-in-hong-kong-purging-andexpanding-ming-pao (accessed 10 November 2016).

Jenkins H (2006) Convergence Culture: Where Old and New Media Collide. New York: New York University Press.

Kokas A (2017) Hollywood Made in China. Oakland, CA: University of California Press.

Kwong Y (2015) The dynamics of mainstream and internet alternative media in Hong Kong: A case study of the umbrella movement. International Journal of China Studies 6(3): 273-295.

Lai CP (2007) Media in Hong Kong: Press Freedom and Political Change, 1967-2005. London: Routledge.

Landler M (2000) Columnist critical of Beijing quits Hong Kong newspaper. Available at: http:// www.nytimes.com/2000/11/07/world/columnist-critical-of-beijing-quits-hong-kong-newspaper.html (accessed November 2016).

Lau J (2008) The narrowing gap: How Hong Kong media is inching towards the China model. Available at: https://reutersinstitute.politics.ox.ac.uk/sites/default/files/THE $\% 20$ NARROWING\%20GAP-\%20Hong\%20Kong\%20and\%20Chinese\%20media\%20models. pdf (accessed 10 November 2016).

Lee C (1998) Press self-censorship and political transition in Hong Kong. The International Journal of Press/politics 3(2): 55-73.

Lee F and Chan J (2010) Media, Social Mobilisation and Mass Protests in Post-colonial Hong Kong: The Power of a Critical Event. London: Routledge.

Levin N and Yung C (2016) An era in Hong Kong is ending, thanks to China tight embrace. Available at: http://www.wsj.com/articles/an-era-in-hong-kong-is-ending-thanks-to-chinastight-embrace-1474647072 (accessed 10 November 2016).

Lin Z (2016) Traditional media, social media, and alternative media in Hong Kong's umbrella movement. Asian Politics \& Policy 8(2): 365-372.

Loh C (2010) Underground Front: The Chinese Communist Party in Hong Kong. Hong Kong: Hong Kong University Press.

Ma N (2007) State: Press relationship in post-1997 Hong Kong: Constant negotiation amidst selfrestraint. The China Quarterly 192: 949-970.

Matthew G, Ma E and Lui TL (2008) Hong Kong, China: Learning to Belong to a Nation. London: Routledge.

Pen America Center (2015) Threatened harbor: Encroachments on press freedom in Hong Kong. Available at: https://pen.org/sites/default/files/PEN-HK-report_1.16_lowres.pdf (accessed 10 November 2016).

Radio Free Asia (2015) Walking with a yellow umbrella, bearing witness to a revolution. Available at: http://www.rfa.org/english/bookshelf/umrevo.pdf (accessed 10 November 2016).

Rawnsley G and Rawnsley M(2003) Political Communications in Greater China: The Construction and Reflection of Identity. New York: Routledge.

Reporters without Borders (2016) Beijing's invisible hand reaches ever deeper into Hong Kong media. Available at: https://rsf.org/en/reports/beijings-invisible-hand-reaches-ever-deeperhong-kong-media (accessed 10 November 2016).

RTHK (2015) SCMP ditches columns by veteran journalists. Available at: http://www.ejinsight.com/20150520-scmp-ditches-veteran-columnists-bowring-rafferty-vines (accessed 10 November 2016).

Sciutto JE (1996) China's muffling of the Hong Kong media. The Annals of the American Academy of Political and Social Science 57: 131-143. 
Shanghaiist (2015) SCMP ditches 4 veteran columnists, including 3 government critics. Available at: http://shanghaiist.com/2015/05/22/scmp-axes-4-veteran-columnists-including-3-gov-critics.php (accessed 10 November 2016).

Shirk S (2010) Changing Media, Changing China. New York: Oxford University Press.

So C (2007) Professionalism, politics and market forces: Survey studies of Hong Kong journalists 1996-2006. Asian Journal of Communication 17(2): 148-158.

Sparks C (2010) China's media in comparative perspective. International Journal of Communication 4: 552-566.

The World Bank (2016) Economy rankings. Available at: http://www.doingbusiness.org/rankings (accessed 10 November 2016).

Timmons H and Guilford G (2014) Hong Kong's protests are over, but the fight over free speech has just begun. Available at: http://qz.com/311287/hong-kongs-protests-are-over-but-thefight-over-free-speech-has-just-begun (accessed 10 November 2016).

Weiss P (2013) Two powerful Chinese media regulators merge. Paul Weiss. Available at: https:// www.paulweiss.com/media/1691033/gapprft2013.pdf (accessed 10 November 2016).

Yeung SC (2014) The Ming Pao headline switch in black and white. Available at: http://www.ejinsight.com/20140703-why-ming-pao-changed-headline-july-2 (accessed 10 November 2016).

Yeung SC (2015) Why print media in Hong Kong is entering an ice age. Available at: http:// www.ejinsight.com/20150717-why-print-media-hong-kong-is-entering-ice-age (accessed 10 November 2016).

\section{Author biographies}

Nicholas Frisch is a doctoral candidate in Asian studies at University of Yale and a Resident Fellow at Yale Law School's Information Society Project.

Valerie Belair-Gagnon is an Assistant Professor of Journalism Studies at the School of Journalism \& Mass Communication and an Affiliated Faculty in the Department of Sociology at the University of Minnesota. She is also an Affiliated Fellow at the Yale Law School's Information Society Project. She is researching and teaching the implications of information technology in news production.

Colin Agur is an Assistant Professor at the School of Journalism \& Mass Communication at the University of Minnesota and an Affiliated Fellow at the Yale Law School's Information Society Project. In 2017-2018, he will be a Residential Faculty Fellow at the Institute for Advanced Study at the University of Minnesota. At the International Communication Association, he is Chair of the Mobile Communication Interest Group and a member of the ICA Board of Directors. His research interests include the history of telecommunications and contemporary mobile phone usage, the social and legal implications of mass mobile telephony, and the unanticipated consequences of network development. 